\title{
Equitable and Inclusive Landscape Restoration Planning: Learning from a Restoration Opportunity Assessment in India ${ }^{\text {a }}$
}

\author{
Ruchika Singh, Karishma Shelar, Marie Duraisami, Will Anderson \\ and Rajendra Singh Gautam
}

\begin{abstract}
Local people must be at the center of restoring landscapes. This paper adapts the popular Restoration Opportunity Assessment Methodology (ROAM), which helps show where land can be restored in a given area by growing trees or protecting forests, to the economically poor yet resource-rich Sidhi District of Madhya Pradesh in India. By employing an intersectional adaptive governance lens and including the perspectives of people and organizations throughout the larger social landscape, we analyzed the multiple benefits landscape restoration can have on ecosystem services, social inclusion, the economy, and local livelihoods. These participatory methods and tools draw attention to the critical socio-economic components of restoration. The findings indicate that different social groups, like powerful men and marginalized women, have different restoration goals (even for tree species selection). They also show that investing in restoration can create thousands of jobs and secure thousands of rural livelihoods. Analyses that produce these socioeconomic insights can inform implementation strategies that are both inclusive and actionable on the ground. They can also identify roadblocks, like unclear land tenure and resource rights, which can impede restoration. Most importantly, these inclusive strategies can ensure that local people serve as more than passive beneficiaries. They place them in their appropriate role as the central stakeholders driving implementation.
\end{abstract}

Keywords: agroforestry, nature-based solutions, social inclusion, social network analysis

\section{\$) Restoration Recap (\%}

- This paper helps people restoring landscapes plan more effective and inclusive projects. It makes three key recommendations to improve the ROAM planning method:

- First, restoration projects must consider the local context and the social landscape. Mapping and analyzing how social groups and organizations interact by bringing people together can help build a shared understanding of the social and ecological goals of restoration.

- Second, local people should be at the center of formulating, designing, and implementing landscape restoration projects. Intersectional overlays of caste, class, and gender influence how decisions are made and projects are run. When the perspectives of marginalized and powerful social groups are seen together, people restoring landscapes can plan more inclusive programs.

- Third, analyzing the economic, livelihood, and employment benefits for local people is important. When restoring land creates jobs and meets local requirements like fuelwood and fodder, local stakeholders are more likely to invest. When planned well, restoration can improve access to key resources and boost local incomes.
2. This open access article is distributed under the terms of the CC-BYNC-ND license (http://creativecommons.org/licenses/by-nc-nd/3.0) and is freely available online at: http://er.uwpress.org

Ecological Restoration Vol. 39, Nos. 1-2, 2021

ISSN 1522-4740 E-ISSN 1543-4079

(O2021 by the Board of Regents of the University of Wisconsin System.
7 here is an emerging global consensus that forest and landscape restoration is one of the cost-effective ways to regenerate nature, while providing sustainable livelihoods for people and staying within 1.5 degrees $\mathrm{C}$ of global warming. Recognizing this opportunity, national governments have made commitments to the Bonn Challenge, Paris Climate Agreement, Aichi Biodiversity Targets, and United Nations Sustainable Development Goals (SDGs). 
In 2019, the UN General Assembly declared 2021-2030 the "Decade on Ecosystem Restoration", with the goal of creating job opportunities, boosting food security, and fighting climate change (UNEP 2019).

To meet these commitments, countries need to systematically plan for restoration, considering local ecological conditions and putting local people at the center. The widely applied Restoration Opportunities Assessment Methodology (ROAM), developed by the International Union for Conservation of Nature (IUCN) and World Resources Institute (WRI), provides a flexible, participatory framework for governments and researchers to identify and analyze the potential for forest and landscape restoration and locate specific areas for interventions like agroforestry (IUCN and WRI 2014).

But these assessments of the biophysical opportunity miss the most important ingredient in successful landscape restoration: the perspectives of local people dependent on natural resources. The original ROAM guidebook did not sufficiently incorporate social inclusion, local voices and livelihoods, and land tenure and resource rights (Chazdon and Guariguata 2018, McLain et al. 2019). While ROAM provides an integrated approach for planning the biophysical side of restoration, it has neglected the "social landscape", or the people living and governing a landscape and how they interact (Buckingham et al. 2018). ROAM analyses have also focused on carbon at the detriment of other ecosystem services, like water and biodiversity.

In this paper, we describe how we adapted ROAM to include key socio-economic variables. Our goal was to more accurately assess the opportunity for restoration in the context of the resource-rich, yet economically impoverished and climate-vulnerable Sidhi district in Madhya Pradesh, India, which faces the challenge of the declining quality of its natural resources. Improving the accuracy of ROAM in India is especially important because of its immense potential for protecting and restoring landscapes, about 140 million hectares (MHa). Local people could claim community forest resource rights on more than 30 MHa of that land (Chaturvedi et al. 2018).

In the last decade, to better understand complex global challenges, researchers are increasingly adopting an interdisciplinary approach (Mollinga 2010, Tobi and Kampen 2018), especially in areas of study that bridge people and nature, like landscape restoration. Place, gender, caste, class, race, and culture determine how people interact with the environment (Clement et al. 2019). The adaptations to ROAM in Sidhi had to capture that diversity and the social, economic, and political contexts through which power operates. In the Indian context, men and women from different castes and economic classes use trees for fuelwood, animal fodder, and non-timber minor forest products (NTFP) differently. Men and women also have unequal access to key networks, knowledge, and information for managing natural resources. ROAM also had to incorporate local knowledge about the appropriate and preferred restoration interventions and tree species to maximize certain ecosystem services. Our findings reflect the complex socio-ecological realities that must be considered when developing an implementation strategy for restoring districts like Sidhi.

In our study, we made additions to ROAM by adjusting three key research questions: 1) Through ecosystem services analysis: What ecosystem services and benefits can be derived from the identified restoration interventions in the targeted landscape? 2) Through social landscape analysis: Who are the actors that can facilitate the implementation of landscape restoration in an area? 3) Through livelihood benefits analysis: What are the livelihood benefits if the identified restoration potential were implemented?

These additions enabled us to integrate the perspectives of diverse stakeholders to inform a more nuanced strategy for transforming Sidhi's landscape. Additional input from gender-responsive restoration guidelines for ROAM exists, which include similar themes (IUCN 2017). These adjustments could be used elsewhere to strengthen engagement and input from diverse stakeholders.

In section two, we begin by defining the landscape approach to restoration. Section three describes how caste, class, gender, and their intersectional overlays can influence people, their interactions with the environment and their priorities for restoration. In sections four and five, we discuss the study site and the ROAM adaptations, focusing on the three research questions. We conclude with section six, which discusses the learnings and relevance of the findings for similar landscapes in India and globally.

\section{The Landscape Approach to Restoration}

A landscape is a heterogeneous mosaic of land uses within a geographical area where ecosystems and political jurisdictions overlap. One group of researchers has called them "problemsheds" because a common environmental problem, like desertification, often affects the entire area and can only be solved through active management (Mollinga et al.2007). Landscape restoration is a long-term process of regaining ecological integrity and enhancing human wellbeing across an unproductive, fragmented, and degraded landscape (Lamb 2014, Chazdon et al. 2017). It includes a range of active and passive techniques to grow trees, such as natural regeneration and agroforestry. A landscape approach to restoration recognizes the interactions between a variety of stakeholders and multiple land uses and posits that environmental and socio-economic problems need to be addressed together (GLF 2014). It can help reach biodiversity and climate goals while sustaining rural livelihoods and enhancing community participation (Chazdon 2008). Since landscape restoration often includes native tree species, it can help reduce habitat fragmentation and restore the conditions necessary for plants, animals, 
and microorganisms to recover (Beatty et al. 2018 and SER 2020).

The landscape approach helps to move away from a singular focus on ecosystem management and towards an integrated perspective that considers the health of the landscape and the flow of ecosystem services, while improving the resilience of rural communities against climate change (IPBES 2019). The impact of 1.5 degrees $C$ of warming will affect different areas and populations in different ways (IPCC 2018). For instance, climate vulnerability manifests differently according to an areas social structures (Ribot 2010). Making landscape restoration strategies more socialand gender-inclusive can help people managing landscapes more accurately prepare for uncertain futures while meeting sustainability and biodiversity targets (Basnett et al. 2017).

Because women and men have access to different resources and land rights-and female-headed households are more vulnerable to social and environmental disturbances-each group may need different strategies to recover from climate-related stress. Gender relations also impact land use and resource decision-making more broadly because people's priorities, access, knowledge, ownership, and use of those resources are influenced by their intersectional identities influenced by gender, caste, and class (Rocheleau et al. 1996, Agarwal 2010). Without considering the views of people with insecure land tenure, we could risk prioritizing privileged social groups while excluding vulnerable populations. For Sidhi, we considered these complex social and ecological dimensions and adjusted ROAM to more accurately assess restoration opportunity.

\section{How to Govern Landscapes with People at the Center}

An adaptive governance lens emphasizes the dynamic link between social and ecological landscapes. Adaptive governance systems are self-organized social networks of actors that draw on various knowledge systems (traditional, local, scientific, etc.) and experiences to develop a shared understanding of progress (Folke et al. 2005). In landscape restoration, these systems recognize the complexity of ecosystems, inherent uncertainty, and unknown feedback loops stemming from the social actions taken to manage natural resources (Chaffin et al. 2014). For adaptive governance systems to develop, leadership and trust-building at the local level-with the participation of diverse actors with different knowledge systems - are critical (Olsson et al. 2004, Folke et al. 2005). Here, the role of "bridging" organizations or individuals become important. They can connect local stakeholders with those working at the regional and national scales, paving the way to exchange knowledge and resources. Adaptive management and self-organization can also lower the cost of collaboration and conflict resolution when they have the support of enabling legislations and government policies (Folke et al. 2005). Conversations between those layers can ensure upward and downward accountability in natural resource management, but their absence seems to be a weak link in several parts of the world (Ribot 2002). Together, all of these actors form the social landscape (or network), a web that helps transfer knowledge and build the necessary legal, political, and financial support for implementing restoration (Pretty 2003).

Landscape restoration occurs over decades, and its path may face several environmental, institutional, political, and social constraints (Bullock et al. 2011, Boyd and Folke 2012). Many restoration projects mention that they include the voices of women and other marginalized groups, but don't include them in substantive decision-making. Over time, projects need to recognize local communities as rightsholders to mitigate that risk (Basnett et al. 2017). Secured tenure and resource rights can help avoid that pitfall. They can also help actors to adapt to external conditions like market changes and future shocks or build a network's collaborative capacity through consensus-building.

\section{Understanding Power Dynamics Underpinning the Social Landscape}

The perspectives of local people are crucial for realizing the ecosystem and economic benefits of restoration. Local knowledge on important tree species (and integrating programs within economic development schemes) underpin restoration success (Chazdon 2008). However, a lack of contextual knowledge on relations between actors and networks-and how each actor uses information, resources, conflicts, influence, and decision-making_can lead to restoration researchers and practitioners to make generalizations (Callon 2001, Steins 2001). Identifying and mapping inter-group relationships in the social landscape helps us understand how people organize around common goals, which can help improve planning (Buckingham et al. 2020).

This is critical because these networks form the foundation of the institutions that are embedded in everyday life and that govern power relationships (Cleaver and de Koning 2015). Understanding intersectional identities and how women and men, for example, exercise power over resources in different ways is key (Clement et al. 2019). Those relationships intertwined with intersectional identities can shed light on where new institutions and relationships can be built and where change can happen (de Koning and Cleaver 2012). More diverse networks set more inclusive and accurate objectives for restoration and can mediate between actors with different interests, power, and resources at different scales to come together and enable shared understanding on restoration. 


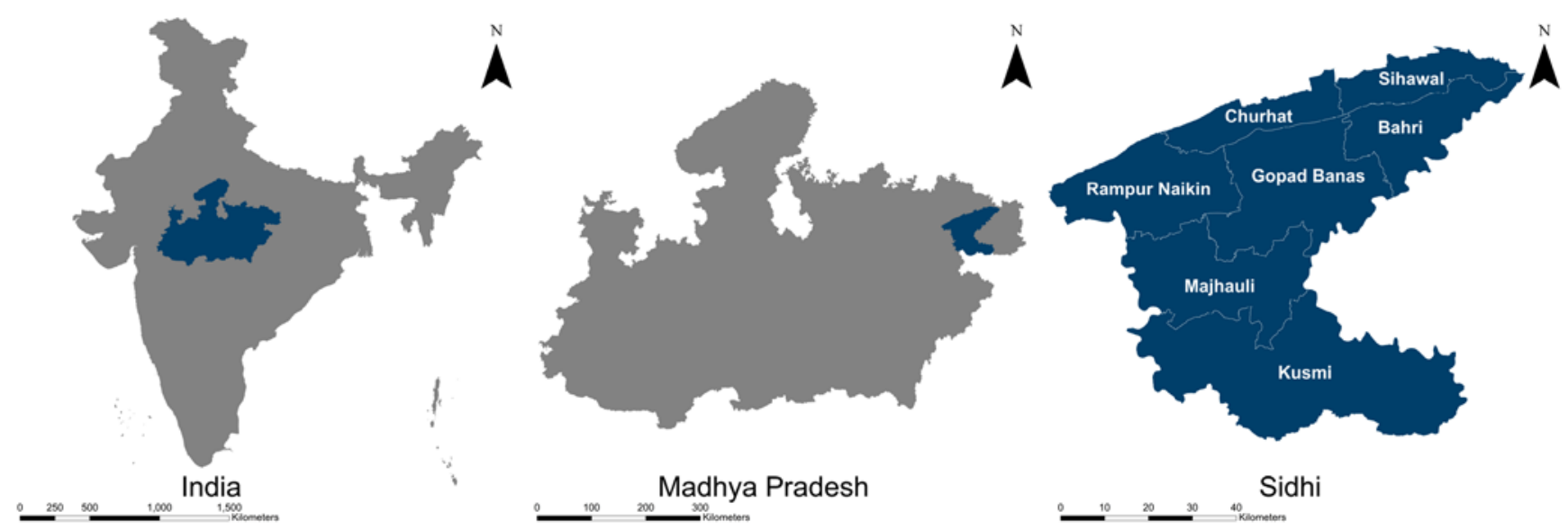

Figure 1. The figure shows the map of Sidhi district (right) where the assessment was undertaken, in the context of India (left) and the state of Madhya Pradesh (middle).

\section{Tenure, Resource Rights, and Access Considerations}

Land tenure and resource rights can influence how restoring landscapes affects different social groups. Tree tenure is location-specific and varies depending on the existing power relations and intersectional identities of gender, caste, and class (Agarwal 2010). Because of that disparity, for example, researchers need to separately assess men's and women's rights to use and access natural resources during different times of the year (Rocheleau and Edmunds 1997). These disparities map onto the intersections of people's individual identities and experiences and can influence how knowledge is shared, socio-political processes develop, and environmental impacts vary (Rocheleau et al. 1996, Nightingale 2006). While planning restoration at the landscape level, we need to consider these differentiated needs and interests.

\section{Study Site}

Sidhi is one of the most economically poor and vulnerable districts in the Central Indian State of Madhya Pradesh. It fares poorly in most development indicators: energy access, household income, healthcare, clean water, and employment (Gosain et al. 2014). The district comprises seven tehsils (sub-districts) and five blocks (the unit for development planning) (Figure 1). Sidhi is predominantly rural, with only four urban centers. It also contains three protected areas: Son Ghariyal Sanctuary, Sanjay Dubri Tiger Reserve, and Bagdara Wildlife Sanctuary.

Agriculture and forests are its primary land uses, accounting for more than $80 \%$ of the geographic area (NRSC 2015). Agriculture is the bedrock of livelihoods for over a million people in Sidhin, nearly $55 \%$ of whom live below the poverty line (Bhanumurthy et al. 2016). Almost $57 \%$ of the population either owns no land, low productivity land, or only their homestead (GoI 2011).
But upper-caste households in Sidhi own large parcels of mostly irrigated and productive lands. Nearly $39 \%$ of the population are from Scheduled Castes (SC), or "dalits", and Scheduled Tribes (ST), or "adivasi" indigenous groups classified under the Constitution of India. They mostly work as agricultural laborers and spend a significant time collecting fuelwood from the forest to meet their energy requirements. In Sidhi, recent changes in forest cover and composition and the declining productivity of land, in combination with social barriers, such as rights to forest resources, existing conflicts over tenure and resource rights, and the removal of land from the commons (e.g., grazing lands), threaten the livelihoods of Sidhi's people. That affects the availability of key resources that local people need, like animal fodder and NTFP.

\section{Methodology}

This section focuses on the three key questions we added to inform a more inclusive restoration opportunity assessment for Sidhi. These adjustments to ROAM aimed at strengthening how we understand inclusion, tenure, and resource access and rights from the perspectives of diverse social groups. This understanding should underpin how to design effective restoration strategies. This is not the first study to adapt ROAM (IUCN 2017), but these adjustments could be used worldwide to build a more nuanced and inclusive strategy for landscape transformation.

\section{Data Collection}

In this district, we adjusted the ROAM by adding three study questions (Table 1). At their core, they use an intersectional approach to identify employment and income opportunities for landless people, youth, women, and marginalized groups within tree-product value chains. A participatory consultative approach that applied innovative tools underpinned our research (Table 1, Q1, Q2). We collected the data using a mixed-methods approach, 
Table 1. The three components of ROAM where modifications were made, highlighting the key questions and methods used for data collection and analysis.

\begin{tabular}{|c|c|c|}
\hline Component & Key Question & Methods: Data Collection and Analysis Tools Used During Consultations \\
\hline $\begin{array}{l}\text { Ecosystem services } \\
\text { analysis } \\
\text { (New addition to } \\
\text { ROAM) }\end{array}$ & $\begin{array}{l}\text { Q1. What ecosystem ser- } \\
\text { vices and benefits can be } \\
\text { derived from the identified } \\
\text { restoration interventions in } \\
\text { the targeted landscape? }\end{array}$ & $\begin{array}{l}\text { Estimations made and areas mapped for biodiversity conservation, erosion } \\
\text { control, carbon sequestration, provisioning of fuelwood based on digital map- } \\
\text { ping and modeling, and stakeholder consultations for identified restoration } \\
\text { interventions. Following the development of the spatial layers through digital } \\
\text { mapping and modeling, the Ecosystem Services Diagnostic Tool developed } \\
\text { by the team was used in the pre-validation workshop, enabling stakeholders } \\
\text { to prioritize competing demands and identify restoration interventions best } \\
\text { suited for delivering the essential ecosystem services. }\end{array}$ \\
\hline
\end{tabular}

Social landscape analysis (New addition to ROAM)

Livelihood analysis (New addition to ROAM)
Q2. Who are the actors that can facilitate the implementation of landscape restoration in an area?

Q3. What are the livelihood benefits if the identified restoration potential were implemented?
Key actors and networks identified through social network analysis using Net-Map—a methodology developed by Schiffer (2007) and improved by Buckingham et al. (2018). Relationship maps made with Kumu, a powerful, free data visualization software. Additionally, the team created a checklist for collecting data from different departments and other sources. To gauge institutional functioning with stakeholders during sub-district consultations, the team developed an institutional checklist before consultations that stakeholders used to reflect the status of local institutions' through different color codes.

Livelihood mapping and profiling at the "gram panchayat" level undertaken with a partner organization yielded a comprehensive list of interventions. These were matched with the identified restoration interventions and were shortlisted for further subsector analysis based on select parameters. Checklist of questions for focus group discussion and household survey questionnaires for assessing livelihood potential and value chain analysis were prepared in advance. including stakeholder consultation workshops, focus group discussions, and a livelihood assessment that matched household surveys with structured and semi-structured interviews. In total, we conducted nine stakeholder consultations (one at state level, four sub-district level, four district level) between July 22, 2016 and February 3, 2018 (Table 2).

We completed a social landscape analysis using NetMap, a methodology developed by Schiffer (2007) and improved by Buckingham et al. (2018). It identifies the structure of a social network-its central actors, shape, and the attributes of its members-to help understand the local context when designing a strategy for change. For a more nuanced analysis, we compared district-level findings to our state-level results for Madhya Pradesh, which included different participants from both the state and district levels.

The Institute of Livelihood Research and Training, Bhopal, led the livelihood assessment and applied a representative, multi-stage sampling technique to conduct a livelihood analysis of 40 "gram panchayats" and 75 villages. Each "gram panchayat" consists of executives elected by the village assembly, which comprises all adults in a village. Additionally, interviews were conducted with actors at pre-production, production and post-production stages to map the value chains of six tree species and to assess the livelihood promotion potential of tree-based value chains and market development (ILRT 2018).

For the eight consultations in Sidhi: four sub-district consultations, two district-level consultations to map the social landscape (or network), two district-level consultations to validate the initial findings with local stakeholders, and one to present the study's results and discuss an implementation strategy, a local partner made a long list of potential participants (Table 2). The list included community leaders, progressive farmers, and elected leaders of local institutions and non-government organizations (NGOs) in the district. The local partner facilitated their participation in these workshops. Information about the consultations was spread by word of mouth and WhatsApp, and participants were encouraged to spread the invite within their networks. Additionally, all relevant government officials were invited for these consultations.

All the workshops, one-to-one meetings, stakeholder mapping at the district level, and focus group discussions in Sidhi were conducted in Hindi. Only the state level inception workshop was conducted in English. A diverse group of stakeholders informed the process of identifying the restoration potential areas and how they would be restored. The sub-district consultations, for example, included representation from farmers (42\%), "gram panchayats" (19\%), government departments (18\%), NGOs (10\%), farmer producer organizations (4\%), members of the "Zilla Panchayat" (elected assembly at the district level) (3\%), members of the "Lok Vaniki" (private forestry group) (2\%), and others (2\%). Initially, ST (4\%) and SC (4\%) groups and women (outside of local NGO staff) were underrepresented in the sub-district consultations. Sidhi is part of the Baghelkhand region, where patriarchal social structures are predominant. Women's mobility and, 
Table 2. The details of stakeholder consultations we conducted to address our key questions, the number of participants, and the profile of participants.

\begin{tabular}{|c|c|c|c|}
\hline $\begin{array}{l}\text { Type of } \\
\text { Consultations }\end{array}$ & $\begin{array}{l}\text { Number and Location } \\
\text { of the Consultations }\end{array}$ & $\begin{array}{l}\text { Number of } \\
\text { Participants }\end{array}$ & Profile of Participants \\
\hline \multirow{2}{*}{$\begin{array}{l}\text { Stakeholder mapping (to } \\
\text { map social landscape-- } \\
\text { actors and networks-for } \\
\text { implementing landscape } \\
\text { restoration) } \\
\text { (Table 1, Q2) }\end{array}$} & $\begin{array}{l}\text { Two. } \\
\text { Bhopal }\end{array}$ & $\begin{array}{l}14 \text { (stakeholders } \\
\text { mapping), } 52\end{array}$ & $\begin{array}{l}\text { Representatives from State Departments, National } \\
\text { Bank for Agriculture and Rural Development } \\
\text { (NABARD), non-government organizations (NGO), } \\
\text { "Zilla Panchayat" elected assembly at district level } \\
\text { (Sidhi and Umaria districts), research institutions, } \\
\text { private sector, retired forest officials, lawyers, media, } \\
\text { a former member of the legislative assembly (MLA). }\end{array}$ \\
\hline & $\begin{array}{l}\text { Two. } \\
\text { Sidhi district } \\
\text { headquarters }\end{array}$ & 12,12 & $\begin{array}{l}\text { Representatives of: district officials (like Rural Develop- } \\
\text { ment, Watershed); locally elected leaders of "gram } \\
\text { panchayat" (village assembly), water-user associa- } \\
\text { tions; farmers; a former MLA; a local community- } \\
\text { based organization (CBO). } \\
\text { Representatives from the Forest Department. }\end{array}$ \\
\hline $\begin{array}{l}\text { Sub-district consultations } \\
\text { (to stock take existing } \\
\text { interventions and key } \\
\text { actors undertaking it; } \\
\text { to map and identify the } \\
\text { potential for restoration } \\
\text { and type of interventions } \\
\text { feasible; to understand } \\
\text { opportunities and chal- } \\
\text { lenges for landscape } \\
\text { restoration) } \\
\text { (Table 1, Q1) }\end{array}$ & $\begin{array}{l}\text { Four. } \\
\text { In different sub-district } \\
\text { locations and Sidhi } \\
\text { district headquarters }\end{array}$ & 82 & $\begin{array}{l}\text { Representatives of: farmers, "gram panchayat" presi- } \\
\text { dents, government departments (like the Forest, Rural } \\
\text { Development, Panchayats, Agriculture Departments), } \\
\text { NGO, CBO, farmer producer organization, "Lok } \\
\text { Vaniki" (private forestry group), and entrepreneurs. }\end{array}$ \\
\hline $\begin{array}{l}\text { Pre-validation work- } \\
\text { shop (to validate initial } \\
\text { findings) } \\
\text { (Table 1, Q1, Q2) }\end{array}$ & $\begin{array}{l}\text { One. } \\
\text { Sidhi district } \\
\text { headquarters }\end{array}$ & 106 & $\begin{array}{l}\text { Representatives of: farmers, local communities, district } \\
\text { administration, farmer producer organizations and } \\
\text { local political leaders. }\end{array}$ \\
\hline $\begin{array}{l}\text { Way forward workshop } \\
\text { (to present the study's } \\
\text { results and discuss an } \\
\text { implementation strategy) } \\
\text { (Table 1, Q1, Q2, Q3) }\end{array}$ & $\begin{array}{l}\text { One. } \\
\text { Sidhi district } \\
\text { headquarters }\end{array}$ & 214 & $\begin{array}{l}\text { Representatives of: state and district level government } \\
\text { officials, political leaders, regional NABARD offi- } \\
\text { cials, farmers, representatives from farmer producer } \\
\text { organizations, CBO, local user groups, community } \\
\text { members, media, NGOs, retired forest officials, and } \\
\text { private sector. }\end{array}$ \\
\hline
\end{tabular}

consequently, their participation are usually restricted in the sub-district consultations. To remedy that imbalance, eight focus group discussions and one-to-one conversations with approximately 80 participants were conducted with follow-up questions in four sub-districts, with 46 women and 39 men. A majority of participants identified themselves as either ST or SC.

We combined local insights with a geospatial analysis consisting of digital and knowledge mapping to identify areas during sub-district consultations that could benefit from different restoration techniques, based on land use and ownership (Table 2, Q1). We also calculated the potential financing it would take to implement each technique. We paired that with a literature review and analyses of policies, past restoration experience in the district, and the current flow of ecosystem services. WWF-India's Centre for Environmental Law looked closely at relevant laws and governing mechanisms.

\section{Results}

Sidhi's ROAM identifies that more than 360,000 ha of land could be restored to address key land use challenges. Participants identified eight different types of landscape restoration interventions based on existing practices and knowledge: assisted natural regeneration, mixed species plantations, trees on farm boundaries, agri-horti-forestry (a type of sustainable orchard combined with crops and timber species grown on farm boundaries, also known as "wadi"), farmer-managed natural regeneration, bamboo plantation, pastureland development, and riverbank plantations. The interventions identified were the most viable to address people's land use challenges like the high dependency on fuelwood as an energy source, the lack of pasture and common land, declining agricultural land productivity, and the loss of natural forests. They also can improve food security, nutrition, and capacity to adapt to climate change (Singh et al. 2020). 

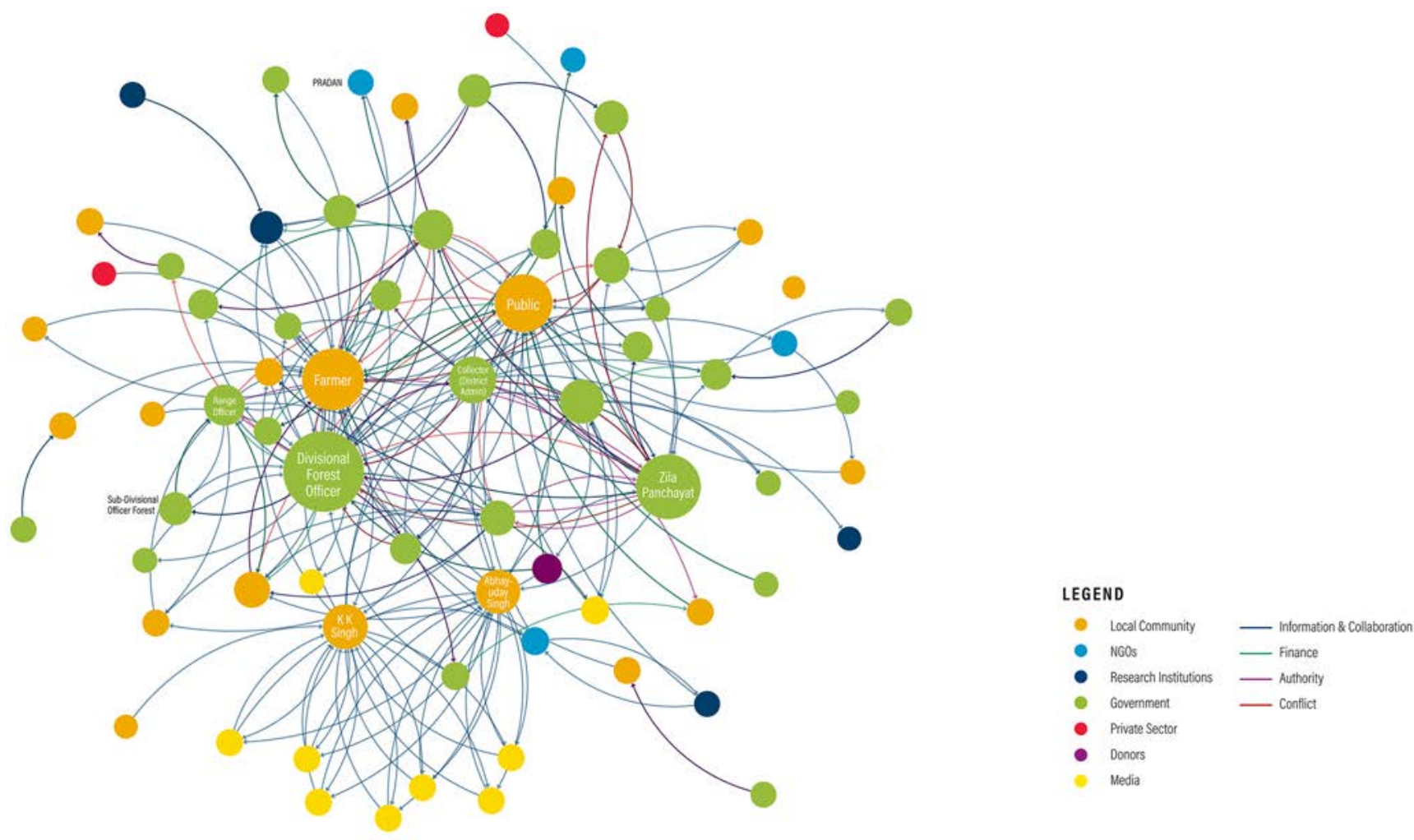

Figure 2. The social landscape of Sidhi (source: Buckingham et al. 2018). The color of the bubbles indicates the type of actors like local community, NGOs, government. The size of the bubble indicates the connectivity of organizations and individuals in the network and influential actors. The color of the lines indicates how network organizations and individuals are connected in terms of exchanging information (blue), flows finance (green), authority relationships (purple), and conflict (red).

\section{Understanding the Social Landscape}

To realize this restoration potential in more than 360,000 ha understanding the social landscape is critical because formal and informal networks disseminate knowledge and information and can play an important role in policy implementation by encouraging cooperation and collaboration (Folke et al. 2005). Our findings indicate that although the network size in Sidhi is large, it lacks a diversity of actors, especially NGOs and the private sector. Most importantly, actors are not aligned around a common goal (Figure 2).

Farmers, though not a homogenous category, emerged as the core of Sidhi's social landscape as the key connectors through whom restoration will happen. Farmers could serve as a bridge for disseminating new information on landscape restoration through the media and environmental awareness campaigns. But creating that bridge will not be simple. The stakeholder mapping and additional fieldwork indicated that the local population in Sidhi is highly politicized, and caste and political affiliations drive and motivate them. The interplay of these social and political dynamics and the negative experiences of farmers with a few private organizations promoting restoration in the past has made them wary of new initiatives. How can this change? For restoration to work, local actors will need to create a shared understanding of success that reflects the priorities and concerns of these farmers, youth, and landless people from different castes and classes.

In Sidhi, there is a strong network of government agencies working on landscape restoration. District-level government agencies, especially the District Collector (who heads the district administration), the "Zilla Panchayat" president, and the Divisional Forest Officer (who heads the forest division in a district), can connect people (Table 3). These actors have restoration as part of their mandates and have the responsibility to share information. Three key actors with authority and access to funding for restoration are the Forest Department, the District Collector's office, and the "Zilla Panchayat's" office. However, these departments rarely coordinate their activities to maximize impact. The Forest Department has acknowledged that it has tense relations with all the other government departments and farmers in the district, creating a barrier to implementing restoration in Sidhi. Any strategy for restoration would require that departments work together and align their investments.

Actors on the periphery of the network can bring in key information from outside the network. In Sidhi, these are institutions like National Bank for Agriculture and Rural Development (NABARD), "Krishi Vigyan Kendra" 
Table 3. A representation of the relative power of actors in the network. Social network analysis uses centrality terminology - centrality measures of degree, closeness, betweenness, and eigenvector-to identify the network's powerful and important actors by looking at how many connections the actor has and whether the actor is connected to other powerful actors. Degree centrality is one type of network centrality, measured as the number of connections held by each actor. Closeness centrality is another type of network centrality, measured as the distance actors are from other actors. Betweenness centrality is measured as the frequency with which the actors lie on the shortest path between other actors. Eigenvector centrality is measured as the extent to which actors are connected to other central actors.

\begin{tabular}{ll}
\hline Centrality & Who? \\
\hline $\begin{array}{l}\text { Connectors } \\
\text { Degree Centrality }\end{array}$ & Divisional Forest Officer, Zilla Panchayat, Farmer, Public, Collector (District Administration) \\
$\begin{array}{l}\text { Spreaders } \\
\text { Closeness Centrality }\end{array}$ & Divisional Forest Officer, Zilla Panchayat, Public, Farmer, Former Member of Legislative Assembly \\
$\begin{array}{l}\text { Gatekeepers } \\
\text { Betweenness Centrality } \\
\text { Change Champions } \\
\text { Eigenvector Centrality }\end{array}$ & Divisional Forest Officer, Farmer, Public, Zilla Panchayat President, Zilla Panchayat \\
\hline
\end{tabular}

(Agriculture Science Centers), the Indira Gandhi National Tribal University in Amarkantak, print journalists, and the few NGOs that have limited presence (yet do not share information). How can they bring in outside expertise more effectively? They can reach out to the more diverse set of actors that our broader social landscapes analysis of Madhya Pradesh identified. The stakeholder map in Figure 3 indicates that the diverse agencies working on landscape restoration in Madhya Pradesh outnumber those working in Sidhi. These include government agencies, the private sector, research institutions, and donors, with local communities still at the center (Buckingham et al. 2018).

To bring their expertise to Sidhi, it would be necessary to reach out to the champions that interact across scales, such as the NABARD, prominent NGOs, and agricultural extension services (like the "Krishi Vigyan Kendras") and encourage them to bring partners into Sidhi. Identifying these actors and networks who can provide key resources to facilitate change and engage those who have the power is crucial (Chaffin et al. 2014). Facilitating a shared vision between these peripheral district-level actors and building up their ties to organizations in Sidhi could accelerate implementation.

\section{Local Priorities, Building Sustainable Livelihoods, and Creating Jobs}

Results from the ROAM indicate that enhancing tree cover has the potential to restore forests across 108,811 ha that are currently degraded or undergoing degradation. Stakeholders who participated in our consultations and workshops identified reducing forest fragmentation as a critical outcome which could be achieved by a combination of interventions such as mixed-species plantation, agroforestry, and bamboo plantation to secure up to 127,182 ha of the fragmented forest areas (Singh et al. 2020).

A past assessment for Madhya Pradesh that analyzed 61 social, economic, agriculture, forest, water, health, and climate indicators identified Sidhi as an extremely climate-vulnerable district (Gosain et al. 2014). Given Sidhi's demographic profile, poor, marginal farmers, and landless people (which are predominantly SC and ST) will suffer disproportionately. To combat that risk, stakeholders said during all consultations that they wanted to prioritize native trees to keep forests intact, reverse soil erosion, boost the resilience of forests to climate change and sustain livelihoods for SC and ST men and women by meeting local demand for food, fuelwood, and fodder.

Customary practices and traditional beliefs that encourage people to protect native species like Ficus religiosa (Peepal) and Azadirachta indica (Neem) are also relevant. During consultations, participants cautioned against developing a restoration strategy that focused solely on growing timber, citing poor experience with private organizations that have propagated teak plantations with a long gestation period, no assured return on investment, and no value for biodiversity, water, and other ecosystem services. Tree-based interventions most preferred by participants during sub-district consultations were agri-horti-forestry or "wadi", for its ability to provide additional income and food security, and trees on farm boundaries or bunds to curb soil erosion. Given the unpredictable nature of monsoons and the lack of irrigation facilities, participants, especially poor members of SCs and STs, highlighted that the tree species chosen should be able to survive on little water.

Tree species selection and type of intervention was especially important for private farmlands. During subdistrict consultations, participants emphasized that the ideal species would differ based on the needs of each socio-economic group. For instance, upper-caste farmers with large landholdings preferred forest farming. In contrast, small and marginal landholders from SC and ST preferred growing home gardens or trees on farm bunds and boundaries to supplement their energy and other domestic requirements. SC and ST households with small 


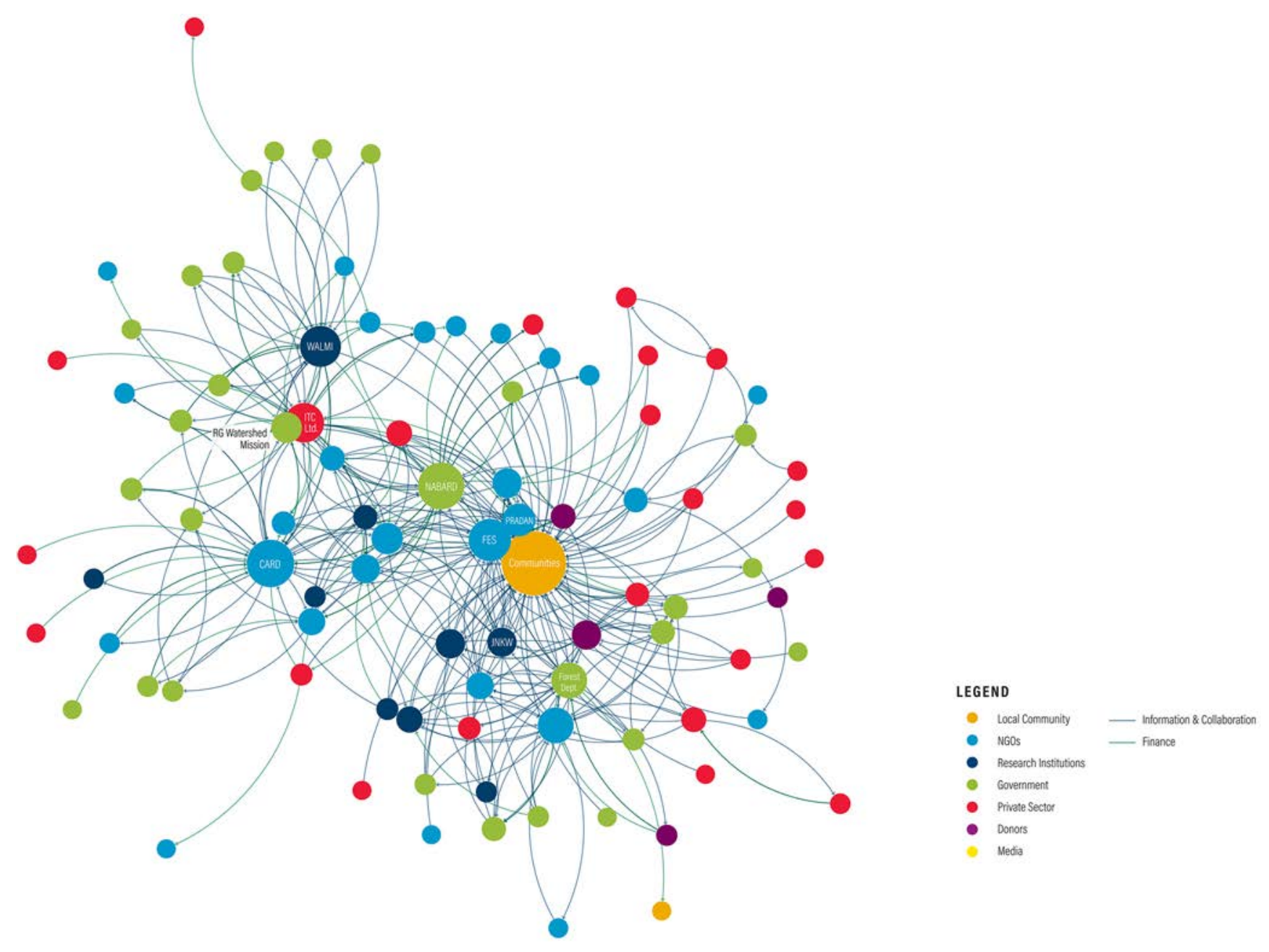

Figure 3. An influence and interest stakeholder map of Madhya Pradesh (source: Buckingham et al. 2018). The color of the bubbles indicates the type of actors like local community, NGOs, government. The size of the bubble indicates the connectivity of organizations and individuals in the network and influential actors. The color of the lines indicates how network organizations and individuals are connected in terms of exchanging information (blue), flows finance (green), authority relationships (purple), and conflict (red).

landholdings emphasized that they needed more water to successfully grow more trees on their homesteads. Because these marginalized groups stressed how beneficial trees on farm boundaries could be, this was included as one of the eight interventions instead of forest farming, which only large landowners can adopt.

For these eight prioritized restoration interventions we did a livelihood assessment of Sidhi which indicates that landscape restoration can create 3.75 million paid working days for local people, creating INR 710 million (USD 10 million) in wage income. Developing value chains for key native tree species-like Madhuca indica (Mahua), Dendrocalamus sp. and Bamboosa sp. (Bamboo), Butea monosperma (Palash), Artocarpus heterophyllus (Jackfruit), Moringa oleifera (Moringa or drumstick tree), and Emblica officinalis (Aonla) - can create 3,000 microenterprises and 30,000 jobs, including for women, unemployed youth and landless people (Singh et al. 2020). These tree species are locally viable, grow in abundance, and are marketable. For instance, jackfruit grows abundantly in-home gardens, but because people have limited access to larger district markets, it is sold at throwaway prices in the local village markets (INR 2-5 per kg).

At almost $60 \%$ of restoration potential in Sidhi, "wadi" (agri-horti-forestry) and growing trees on farm bunds or boundaries could also support sustainable livelihoods. To realize that potential, people will need to grow native tree species that complement agricultural production. Local people identified during consultations that the Butea monosperma (palash) tree, for example, would be a versatile species for agroforestry. From extracting Azadirachta indica (neem) oil to growing cattle feed and creating handicrafts, the variety of tree-product enterprises is diverse. Village microenterprises that trade, process, and retail these products can ensure that women and the landless benefit from these value chains. Local cluster federations and producer companies can reduce the barriers to entry for these fledgling companies. Bringing in connectors like NGOs, research 
institutions and the private sector can also help ensure that restoration businesses are inclusive and that people in power share benefits with vulnerable populations.

\section{Using Intersectional Analysis to Prioritize Ecosystem Services}

One of the assessment's key findings is that developing strategies for landscape restoration in Sidhi ought to be informed by local priorities on the flow of ecosystem services, but every social group can have its own set of priorities.

During district-level consultations, upper-caste men identified erosion control, water recharge, biodiversity conservation, and food provisioning as critical ecosystem services that they wanted to see in the restored landscape. In Majhauli and Kusmi sub-districts, they said that water, food, and soil health needed improvement. Because these regions have relatively high forest cover, the upper-caste men said that they already had enough fuelwood, fodder, and non-timber forest products. However, ST and SC women and men from the same regions, who had no land other than their small homesteads, disagreed. Because of weak and unclear tenure and the lack of common land and resources, they said that they could not gather enough fuelwood or fodder from the forest. When the government designated the nearby forest as part of the buffer zone of the Sanjay Dubri Tiger Reserve, they could no longer collect what they needed from the newly protected area, even though the Scheduled Tribes and Other Traditional Forest Dwellers (Recognition of Forest Rights) Act, 2006 (FRA) recognizes ownership, use, and management rights for India's forest-dependent populations. The FRA, however, is poorly implemented in the region, primarily due to the unwillingness of the Forest Department.

During focus group discussions in Rampur Naikin and Churhat sub-districts, upper-caste women wanted to increase the amount of food that the forest provisioned. In contrast, SC and ST women and men identified fuelwood as the priority because the region's lack of tree cover outside of the forest areas makes it difficult to meet demand. Focus group and one-to-one consultations with uppercaste men and women from Rampur Naikin and Churhat indicated that they do not rely on the forest to meet their energy demand as they had a gas connections. For them, any additional requirement for firewood was met through trees on their farm bunds or boundaries.

Overall, the most prioritized ecosystem services during all district-level consultations, where SC and ST members were less represented, were biodiversity, water recharge, and soil health-the exact benefits that upper caste men prioritized. This explains why purposefully, including the perspectives of marginalized communities, is critically important.

Access to knowledge and resources are also gendered. For instance, during focus groups, the lack of land titles that included SC and ST women's names, access to institutional credit, or participation in gram sabha/village council meetings were concerning. SC and ST women indicated they want to participate in gram sabha meetings. However, they were not aware when the meetings were convened by "gram panchayat" presidents. In some of the focus group discussions with upper-caste women, who were also members of the "gram panchayat", their husbands made most of the everyday decisions. Women's work and their role in agriculture, animal husbandry, home gardening, and the collection of NTFPs are less recognized. In the case of poorer SC and ST communities, women provide for their families and engage in local markets ("haats"). When restoring a landscape, we must take into account these differentiated priorities, rights, roles, and responsibilities while coming to a shared understanding of the objectives of restoration, the location of different interventions, and the selection of species (Basnett et al. 2017). Also, it is important to recognize that restoration projects could increase the burden of women's work and that whom the benefits flow depends on intra-household power relations. Our findings reflect the complex social-nature reality of the local context and why taking all of it into account is an important part of a comprehensive restoration opportunities assessment.

\section{Discussion and Conclusion}

Incorporating the local context into our ROAM assessment of Sidhi taught us three key lessons that are important for restoration practitioners and researchers. First, landscape restoration should focus on more than the biophysical benefits. In the journey toward restoring any landscape, there will be people with more power and some with less. By studying the social landscape, people restoring landscapes can design programs that explicitly help the marginalized people (SC and ST people in the case of India), the poor, and women. Only by understanding who controls resources, the flow of information, and areas of conflict can people develop inclusive restoration programs. Once we understand the social landscape, we can change it by lifting the voices of marginalized people and incorporating groups at the periphery, like NGOs and the private sector, that can provide new resources and mediate conflict. Together, they can build a collaborative, shared vision of understanding that works with governments, communities, and businesses to align current investment and accelerate action.

Second, restoration researchers and practitioners need to assess the many ecosystem services that restoring land can improve. While growing trees does store carbon and builds up climate resilience, local people may have different goals, like accessing fuelwood or improving water quality. Men and women and people from privileged and marginalized social groups will likely disagree on what goals they want to achieve by restoring land. But understanding the many ecological benefits of restoration is a first step toward 
building a compromise that achieves the most goals for the most people. This complex interplay between environmental benefits and the social landscape cannot be ignored.

Third, restoration researchers and practitioners should assess and promote the economic and livelihood benefits of restoration. Developing sustainable value chains around native trees can create thousands of jobs and sources of revenue for poor and marginalized people in Sidhi and other landscapes. Building those businesses is not easy, and there will likely be roadblocks at the pre-production, production, processing, and post-production stages. To build capacity, governments and private funders can invest in local entrepreneurs whose small businesses steer benefits to women and other marginalized groups. Organizing self-help and producer groups and community nurseries can also help improve the skills of people and train them for the workforce.

A more nuanced ROAM assessment like the one we completed in Sidhi makes a robust case for restoring landscapes to improve livelihoods, ensure food security, and create jobs for women, youth, and landless people. During the UN Decade on Ecosystem Restoration (2021-2030), this approach can help other restoration practitioners in India and around the world understand how to take the theory behind the interdisciplinary and participatory landscape approach and apply it to real-life programs. By embracing the social landscape and local context in all its complexity, we can more accurately show the true opportunity of restoration and create inclusive, effective, restoration plans that help achieve the SDGs and global Bonn Challenge while cutting through social inequalities. Only by embracing social inclusion and sustainability together can we restore more land-and help more people-faster.

\section{Acknowledgments}

Crucial for this work was the financial support from the Good Energies Foundation and the framework of the GEF project "Building the Foundation for Forest Landscape Restoration at Scale" executed in five countries (India, Indonesia, Niger, Kenya, and Ethiopia) with implementation supported by UN Environment. Support and contributions of partner organizations, the Centre for Environmental Law (CEL), World Wide Fund for Nature-India (WWF-India), Institute of Livelihood Research and Training (ILRT) in this research, and local partners and stakeholders and communities in Sidhi, are duly acknowledged. Funding for open access was provided by the CGIAR Research Programs on Forests, Trees and Agroforestry; Water, Land and Ecosystems; and Policies, Institutions, and Markets.

\section{References}

Agarwal, B. 2010. Gender and Green Governance: The Political Economy of Women's Presence Within and Beyond Community Forestry. New Delhi, India: Oxford University Press.

Basnett, B.S., M. Elias, M. Ihalainen and A.M.P. Valencia. 2017. Gender matters in forest landscape restoration: a framework for design and evaluation. Bogor, Indonesia: Center for International Forestry Research (CIFOR).

Beatty, C., N.A. Cox, and M. Kuzee. 2018. Biodiversity guidelines for forest landscape restoration opportunities assessments. 1st ed. Gland, Switzerland: International Union for Conservation of Nature (IUCN).

Bhanumurthy, N.R., H.K. A, Nath, S. Bose, P.D. Adhikari and A. Jana. 2016. Madhya Pradesh State MDG Report 2014-15. Bhopal, India: National Institute of Public Finance and Policy (NIPFP) in collaboration with the United Nations Children's Fund (UNICEF).

Boyd, E. and C. Folke. 2012. Adapting institutions: governance, complexity, and social-ecological resilience. In E. Boyd and C. Folke (eds), Adapting Institutions: Governance, Complexity, and SocialEcological Resilience. New York, NY: Cambridge University Press.

Buckingham K., S. Ray, B. Arakwiye, A, Morales, R. Singh, D. Maneerattana, et. al. 2018. Mapping Social Landscapes: A Guide to Restoration Opportunities Mapping. Washington, DC: World Resources Institute.

Buckingham, K., B. Arakwiye, S. Ray, O. Maneerattana and W. Anderson. 2020. Cultivating networks and mapping social landscapes: How to understand restoration governance in Rwanda. Land Use Policy: 104546.

Bullock, J.M., J. Aronson, A.C. Newton, R.F. Pywell and J.M. ReyBenayas. 2011. Restoration of ecosystem services and biodiversity: Conflicts and opportunities. Trends in Ecology and Evolution 26:8.

Callon, M. 2001. Actor Network Theory. Pages 62-66 in N.J. Smelser and P.B. Baltes (eds), International Encyclopedia of the Social \& Behavioral Sciences. Amsterdam, Netherlands: Elsevier.

Chaffin, B.C., H. Gosnell and B.A. Cosens. 2014. A decade of adaptive governance scholarship: Synthesis and future directions. Ecology and Society 19:56.

Chaturvedi, R., M. Duraisami, K.M. Jayahari, C.B. Kanchana, R. Singh, S. Segarin, et. al. 2018. Technical Note-Restoration Opportunities Atlas of India. Mumbai, India: World Resources Institute India.

Chazdon, R.L. 2008. Beyond deforestation: Restoring forests and ecosystem services on degraded lands. Science 320:1458-60.

Chazdon, R.L., P. HS. Brancalion, D. Lamb, L. Laestadius, M. Calmon, and C. Kumar. 2017. A policy-driven knowledge agenda for global forest and landscape restoration. Conservation Letters 10:125-32.

Chazdon R.L. and M. Guariguata. 2018. Decision support tools for forest landscape restoration: Current status and future outlook. In Occasional Paper 183. Bogor, Indonesia: CIFOR.

Cleaver, F. and J. de Koning. 2015. Furthering critical institutionalism. International Journal of the Commons 9:1-18.

de Koning, J. and F. Cleaver. 2012. Institutional Bricolage in Community Forestry: An Agenda for Future Research. Pages 277-90 in B. Arts, S. Van Bommel, M. Ros-tonen and G. Verschoor (eds), Forest-People Interfaces: Understanding Community Forestry and Biocultural Diversity, Wageningen, Netherlands: Wageningen Academic Publishers.

Clement, F., W.J. Harcourt, D. Joshi, and C. Sato. 2019. Feminist political ecologies of the commons and commoning (editorial to the special feature). International Journal of the Commons 13:1-15.

Folke, C., T. Hahn, P. Olsson, and J. Norberg. 2005. Adaptive governance of social-ecological systems. Annual Review of Environment and Resources 30:441-73.

Global Landscapes Forum (GLF). 2014. Global Landscapes Forum Website. Global Landscape Forum available at www.landscapes. org/glf-2014/about (accessed December 23, 2020). 
Government of India (GoI). 2011. District Table (Tehsil-Wise Distribution of Number \& Area of Operational Holdings by Size Class/Size Group). Agriculture Census Division, Department of Agriculture, Co-Operation \& Farmers Welfare Ministry of Agriculture \& Farmers Welfare, Government of India. agcensus. dacnet.nic.in.

Gosain, A.K., N.H. Ravindranath, A. Garg, S. Rao, and INRM Team. 2014. Vulnerability Assessment of Madhya Pradesh Towards Climate Change-a Study under the MOEFF-GIZ Project on Climate Change Adaptation in Rural Areas in India. Bhopal, India: EPCO.

Institue of Livelihood Research and Training (ILRT). 2018. Undertaking Livelihoods Assessment for Eastern Madhya Pradesh Landscape: A Study of Sidhi District. edited by R.S. Gautam, T. Navin, U.S. Sharma, S. Singh, S. Kumar and V. Mahajan. Report submitted to World Resources Institute India. Bhopal, India: ILRT.

Intergovernmental Science-Policy Platform on Biodiversity and Ecosystem Services (IPBES). 2019. Summary for Policymakers of the Global Assessment Report on Biodiversity and Ecosystem Services of the Intergovernmental Science-Policy Platform on Biodiversity and Ecosystem Services. J. Settele S. Díaz, E.S. Brondízio E.S., H.T. Ngo, M. Guèze, J. Agard, et al. (eds). Bonn, Germany: IPBES secretariat.

Inter Governmental Panel on Climate Change (IPCC). 2018. Summary for Policymakers. p. 32 in P. Zhai, V. Masson-Delmotte, H.O. Pörtner, D. Roberts, J. Skea, P.R. Shukla, et al. (eds), Global Warming of $1.5^{\circ} \mathrm{C}$. An IPCC Special Report on the Impacts of Global Warming of $1.5^{\circ} \mathrm{C}$ above Pre-Industrial Levels and Related Global Greenhouse Gas Emission Pathways, in the Context of Strengthening the Global Response to the Threat of Climate Change, Sustainable Development, and Efforts to Eradicate Poverty. Geneva, Switzerland: World Meteorological Organization.

International Union for Conservation of Nature (IUCN) and World Resources Institute (WRI). 2014. A guide to the Restoration Opportunities Assessment Methodology (ROAM): Assessing forest landscape restoration opportunities at the national or sub-national level. In: Working Paper (Road-test edition). Gland, Switzerland: IUCN.

IUCN. 2017. Gender-Responsive Restoration Guidelines: A Closer Look at Gender in the Restoration Opportunities Assessment Methodology. Gland, Switzerland: IUCN.

Lamb, D. 2014. Large-Scale Forest Restoration. New York, NY: Routledge.

McLain, R, S. Lawry, M.R. Guariguata, and J. Reed J. 2019. Integrating Tenure and Governance into Assessments of Forest Landscape Restoration Opportunities. Bogor Indonesia: CIFOR.

Mollinga, P.P., R.S. Meinzen-Dick, and D.J. Merrey. 2007. Politics, plurality and problemsheds: a strategic approach for reform of agricultural water resources management. Development Policy Review 25:699-719.

Mollinga, P. 2010. Boundary Concepts for Interdisciplinary Analysis of Irrigation Water Management in South Asia. In ZEF Working Paper Series, No. 64. Bonn, Germany: University of Bonn, Center for Development Research (ZEF).

Nightingale, A. 2006. The nature of gender: work, gender, and environment. Environment and Planning D: Society and Space, no. 24:165-185.

National Remote Sensing Centre (NRSC). 2015. Land Use and Land Cover for Sidhi District, Madhya Pradesh.

Olsson, P., C. Folke and T. Hahn. 2004. Social-ecological transformation for ecosystem management: the development of adaptive co-management of a wetland landscape in southern Sweden. Ecology and Society 9:2.

Pretty, J. 2003. Social capital and the collective management of resources. Science, no 302: 1912-14.

Ribot, J.C. 2002. African decentralization: Local actors, powers and accountability. In Democracy, Governance and Human RightsPaper Number 8, 103. Geneva, Switzerland: United Nations Research Institute for Social Development.

Ribot, J. 2010. Vulnerability does not fall from the sky: Toward multiscale, pro-poor climate policy. Pages 47-74 in R Mearns and A Norton (eds), Social Dimensions of Climate Change: Equity and Vulnerability in a Warming World, Washington, DC: The World Bank.

Rocheleau, D.E., Thomas-Slayter, B.P. and Wangari, E. 1996. Feminist Political Ecology: Global Issues And Local Experiences. New York, NY: Routledge.

Rocheleau, D and D. Edmunds. 1997. Women, men and trees: gender, power and property in forest and agrarian landscapes. World Development 25:1351-71.

Schiffer, E. 2007. Net-Map Toolbox: Influence Mapping of Social Networks.

Singh, R., K. Shelar, R. Chaturvedi, M. Duraisami and R.S. Gautam. 2020. Restoring landscapes in india for climate and communities: Key findings from Madhya Pradesh's Sidhi district, Mumbai, India: World Resources Institute India.

Society for Ecological Restoration (SER). 2020 What Is Ecological Restoration?" Society for Ecological Restoration, www.serrrc.org/what-is-ecological-restoration (accessed on November 5, 2020).

Steins, N.A. 2001. New Directions in Natural Resource Management the Offer of Actor-Network Theory." IDS Bulletin 32:18-25.

United Nations Environment Programme (UNEP). 2019. New UN Decade on Ecosystem Restoration offers unparalleled opportunity for job creation, food security and addressing climate change. In United Nations Environment Programme (UNEP) and Food and Agriculture Organization (FAO), New York.

Tobi, H. and J.K. Kampen. 2018. Research Design: The Methodology for Interdisciplinary Research Framework. Quality and Quantity, 52:1209-25.

Ruchika Singh (corresponding author) World Resources Institute India, Sustainable Landscapes and Restoration, AADI, 2 Balbir Saxena Marg, New Delhi, Delhi 110016, India, ruchika.singh@wri.org.

Karishma Shelar, International Institute of Social Studies, The Hague, The Netherlands.

Marie Duraisami, World Resources Institute India, New Delhi, India.

Will Anderson, World Resources Institute, Washington DC, USA.

Rajendra Singh Gautam, Institute of Livelihood Research and Training, Bhopal, India. 